\title{
Virtual Tour Instansi Pemerintahan Kabupaten Minahasa Tenggara
}

Bryant R. S. Ngongoloy, Yaulie D.Y. Rindengan, Sherwin R.U.A. Sompie. Teknik Informatika Universitas Sam Ratulangi Manado, J1. Kampus Bahu-Unsrat Manado, 95115 skybryant88@gmail.com, rindengan@unsrat.ac.id, aldo@unsrat.ac.id

\begin{abstract}
Abstrak - Dalam era globalisasi perkembangan zaman yang diikuti dengan generasi perkembangan teknologi, sehingga inovasi terus muncul dalam setiap generasi. Salah satunya media interaktif Virtual Tour yang menjadi inovasi untuk pengenalan suatu lokasi dan memberikan informasi. Inovasi dalam hal pengenalan sebuah instansi pemerintahan masih tergolong minim dibidang media teknologi khususnya Virtual Tour. Skripsi dengan judul Virtual Tour Instansi Pemerintahan Kabupaten Minahasa Tenggara ini dibuat untuk pengembangan aplikasi media interaktif yang dapat menampilkan informasi secara visual dari suatu tempat Instansi Pemerintahan di Kabupaten Minahasa Tenggara. Dalam penelitian ini metode yang digunakan sebagai tahapan penelitian adalah metode Multimedia Development Life Cycle (MDLC) yang menjadi metode rancang bangun perangkat lunak multimedia yang menekankan pada 6 tahap pengembangan multimedia. Tools yang digunakan dalam aplikasi ini adalah Easypano Panoweaver, Easypano Tourweaver, dan Adobe Photoshop CS6, Adobe Premier CS6. Dalam aplikasi ini dimana pengguna bisa melihat keadaan $360^{\circ}$ lokasi instansi pemerintahan Kabupaten Minahasa Tenggara di 21 spot. Dalam merepresentasikan informasi dalam bentuk gambar panorama $360^{\circ}$ dimana memudahkan pengguna untuk melihat informasi secara visual dari suatu lokasi Instansi Pemerintahan di Kabupaten Minahasa Tenggara.

Kata kunci : Virtual Reality Photography, Android, Multimedia Development Life Cycle.
\end{abstract}

\section{PENDAHULUAN}

Sesuai dengan perkembangan zaman hampir semua operasional sudah didukung dengan aplikasi berbasis teknologi. Hal ini dikarenakan perkembangan teknologi yang semakin hari semakin pesat, sehingga memunculkan banyak inovasi baru dari teknologi. Teknologi Virtual Tour merupakan salah satu inovasi yang saat ini begitu bermanfaat bagi pengguna teknologi. Virtual Tour merupakan teknologi yang menempatkan user di dalam gambar dan memungkinkan user untuk meningkatkan kesadaran situasional serta meningkatkan daya lihat, tangkap dan menganalisa data virtual secara signifikan. Virtual Tour sendiri biasanya digunakan untuk memberi pengalaman 'pernah berada' di suatu tempat hanya dengan melihat layar monitor.

Dengan demikian pelayanan masyarakat harus dikembangkan agar adanya kemudahan masyarakat untuk mendapatkan pelayanan menggunakan teknologi Virtual
Tour dan aplikasi ini juga dibangun untuk mempermudah dalam pengenalan Kantor Bupati serta instansi yang ada sambil mempertimbangkan batasan-batasan di atas. Aplikasi dibuat menjadi foto panorama sehingga aplikasi mobile ini dirancang menampilkan daerah sekitar dalam titik tertentu.

\section{LANDASAN TEORI}

\section{A. Virtual Tour}

Dalam jurnal yang disusun oleh Daud F. (2016), Virtual Tour merupakan teknologi yang menempatkan user di dalam gambar dan memungkinkan user untuk meningkatkan kesadaran situasional serta meningkatkan kesadaran situasional serta meningkatkan daya lihat, tangkap dan menganalisa data virtual secara signifikan. ${ }^{[1]}$

Virtual Tour merupakan sebuah simulasi dari sebuah lokasi yang terdiri dari rentetan. Rentetan gambar tersebut akan digabungkan (stich) untuk menghasilkan foto panorama 360 derajat. Virtual Tour sendiri biasanya digunakan untuk memberi pengalaman 'pernah berada' di suatu tempat hanya dengan melihat layar monitor. Penyajian virtual tour dapat dilakukan dengan cara memanfaatkan gambar ataupun video, selain itu dapat menggunakan model 3 dimensi. Untuk penyajian dengan menggunakan gambar, dapat digunakan foto panorama. Pemilihan jenis foto panorama juga mempengaruhi hasil virtual tour yang dihasilkan. Untuk panorama jenis clyndrical, bagian vertikalnya hanya dapat menangkap tidak lebih dari 180 derajat sedangkan jenis spherical, memungkinkan untuk melihat ke atas dan kebawah. ${ }^{[2]}$

\section{B. Multimedia}

Pengertian Multimedia adalah interaksi antara teks, suara, gambar statis, animasi, dan video (Perry, 1994). Ditinjau dari kata-kata pembentukannya, multimedia berarti "melibatkan berbagai media". Dengan menggunakan multimedia, informasi dapat ditampilkan secara serentak melalui berbagai media. ${ }^{[3]}$

\section{Panoweaver}

Panoweaver adalah software stiching panorama yang melakukan proses jahitan dari beberapa baris gambar yang diambil oleh lensa normal, lensa wideangle, dan lensa fisheye. Panorama dapat dibuat secara otomatis dengan mengklik satu tombol. Selain jahitan panorama, Panoweaver bisa ekspor gambar panorama $360^{\circ}$ ke dalam Flash $V R$, QuickTime VR, HTML5 dan App. ${ }^{[6]}$ 
D. Easypano Tourweaver

Easypano Tourweaver adalah program untuk menciptakan aplikasi flash dengan kumpulan foto panorama 360. Software Tourweaver juga mendukung beberapa fitur seperti Popupwindow pada virtual tour, kustomisasi dari Scene Viewer seperti text area berfungsi untuk menampilkan petunjuk dari komponen virtual tour. Begitu juga dengan fitur mengetahui letak dan posisi seperti hotspot, tombol dan radar. ${ }^{[6]}$

\section{E. Metode Multimedia Development Life Cycle (MDLC)}

Metodologi yang digunakan adalah MDLC (Multimedia Development Life Cycle) bersumber dari Luther (1994) dijelaskan oleh Sutopo dalam Aplikasi Multimedia dalam pendidikan (2011) yang terdiri atas 6 tahapan yaitu Concept, Design, Material Collecting, Assembly, Testing, Distribution, harus dimulai dimulai dari concept dan diakhiri dengan tahap distribution, sedangkan tahap Material Collecting dapat dikerjakan secara parallel dengan tahap Assembly.( Sutopo, A.H, 2003). ${ }^{[10]}$

\section{METODOLOGI PENELITIAN}

Dalam penelitian ini digunakan metodologi pengembangan aplikasi yang digunakan adalah MDLC (Multimedia Development Life Cycle). Metodologi ini memiliki 6 tahapan, yaitu : Concept (Pengonsepan), Design (Perancangan), Material Collecting (Mengumpulkan bahan), Assembly (Tahap Pembuatan), Testing (Tahap Percobaan), dan Distribution (Tahap Evaluasi) terlihat pada gambar 1.

Metodologi ini sangat cocok dikarenakan metodologi ini sangat cocok digunakan untuk pengembangan aplikasi berbasis multimedia, hal ini dilihat dari ke-6 tahap yang bisa merangkum semua dalam pengembangan aplikasi multimedia. Jika dalam pengembangan, data yang digunakan masih kurang atau rusak, maka metode ini memberikan kesempatan untuk melakukan pengambilan data kembali. Hal ini bisa terjadi karena metodologi ini memungkinkan tahap pengumpulan data dan pembuatan dapat berjalan secara bersamaan.

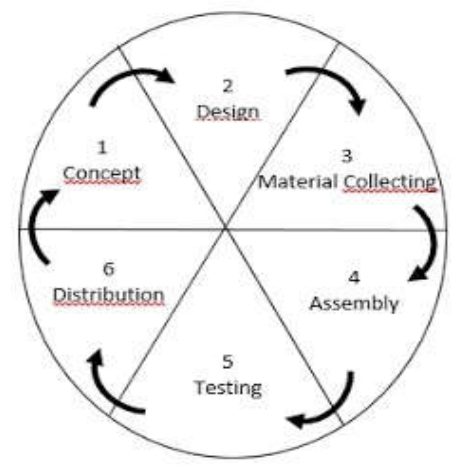

Gambar 1. Tahapaan pengembangan multimedia. Sumber : Ariesto Hadi, Sutopo. (2003)
TABEL I

KONSEP MULTIMEDIA INTERAKTIF

\begin{tabular}{|l|l|}
\hline Judul & $\begin{array}{l}\text { Virtual Tour Instansi Pemerintahan } \\
\text { Kabupaten Minahasa Tenggara }\end{array}$ \\
\hline Tujuan & $\begin{array}{l}\text { Memperkenalkan Instansi } \\
\text { Pemerintahan Kabupaten Minahasa } \\
\text { Tenggara dan memberikan informasi } \\
\text { secara visual dengan foto panorama } \\
360^{\circ}\end{array}$ \\
\hline $\begin{array}{l}\text { Pengguna } \\
\text { Akhir }\end{array}$ & Masyarakat Umum \\
\hline Objek Virtual & $\begin{array}{l}\text { Konten Multimedia } \text { yaitu foto dan } \\
\text { video }\end{array}$ \\
\hline Input & Foto, Teks, dan Video \\
\hline Output & Foto panorama $360^{\circ}$ dan teks \\
\hline
\end{tabular}

\section{A. Concept}

Pembuatan susunan perencanaan pembuatan aplikasi dalam hal melengkapi dan mencapai tujuan dari penelitian yang berdasarkan dari latar belakang masalah. Aplikasi ini memungkinkan pengguna (user) bisa melihat secara menyeluruh dan menampilkan infomasi tentang tugas pokok dan fungsi dari setiap instansi juga memberikan informasi tentang layanan publik dalam pengurusan keperluan masyarakat umum dengan menggunakan teknologi virtual tour. Konsep tersebut dirangkum dalam sebuah tabel, seperti tabel 1.
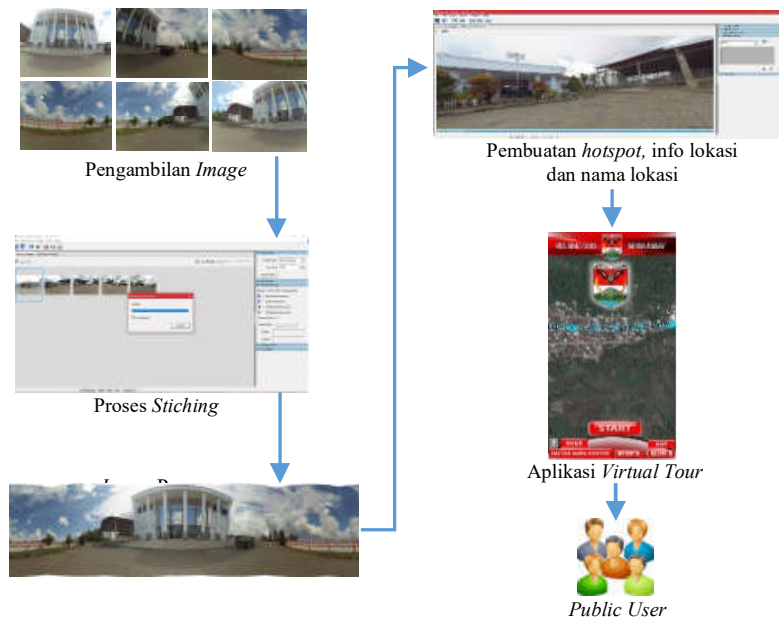

Gambar 2. Design Sistem

B. Design

Virtual Tour dibuat dengan tour panorama lokasi dan ditampilkan informasi mengenai objek yang ada pada panorama. Pembuatan virtual tour dilakukan dengan pengambilan beberapa foto lokasi kemudian dilakukan 
proses stiching (dijahit) untuk menggabungkan beberapa foto lokasi menjadi panorama.

Pembuatan virtual tour menggunakan beberapa foto panorama dan mengabungkan foto panorama tersebut sehingga sehingga terbentuk suatu rute tour. Hasil virtual tour kemudian dipublikasikan sehingga dapat diakses oleh masyarakat umum dan dapat dijadikan sebagai alternatif media untuk memperkenalkan lokasi yang ada di instansi Pemerintahan Kabupaten Minahasa Tenggara nantinya. Alur design sistem ditunjukkan pada gambar 2.

Storyboard yang menggambarkan tampilan aplikasi yang akan dibuat, dapat dilihat pada tabel II. Tahapan ini meliputi tahap pembuatan tampilan dan kebutuhan material untuk pengembangan aplikasi ini.

Use case diagram adalah representasi visual yang mewakili interaksi antara pengguna dan sistem informasi dalam UML. Jadi, dapat disimpulkan bahwa use case diagram adalah diagram yang merupakan representasi visual yang mewakili interaksi antara pengguna dan sistem informasi untuk menunjukan peran dari pengguna dan bagaimana peran - peran menggunakan sistem.

Dalam tahap perancangan aplikasi ini dibuat sebuah Use Case Diagram untuk memperjelas proses yang berjalan dari sistem ke pengguna aplikasi akan terlihat pada gambar 3 .

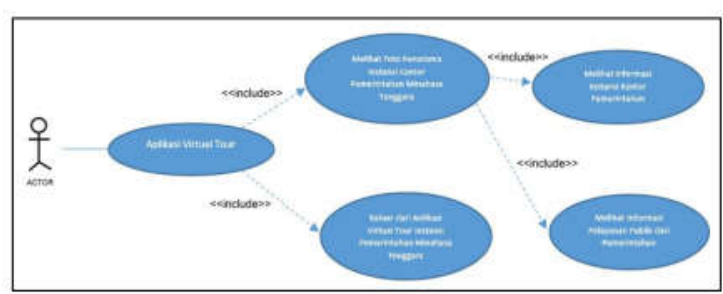

Gambar 3. Use Case Diagram

TABEL II

STORYBOARD APLIKASI

\begin{tabular}{|c|c|c|}
\hline Scene & Visual & Description \\
\hline 1 & OCMOME & $\begin{array}{l}\text { Halaman awal aplikasi } \\
\text { Virtual Tour adalah } \\
\text { gambar panorama } 360^{\circ} \\
\text { dan terdapat } 6 \text { buah } \\
\text { button yaitu : home, } \\
\text { map, blok, help, dan } \\
\text { daftar. Button blok } \\
\text { digunakan untuk } \\
\text { berpindah lokasi blok A } \\
\text { maupun blok B. }\end{array}$ \\
\hline
\end{tabular}

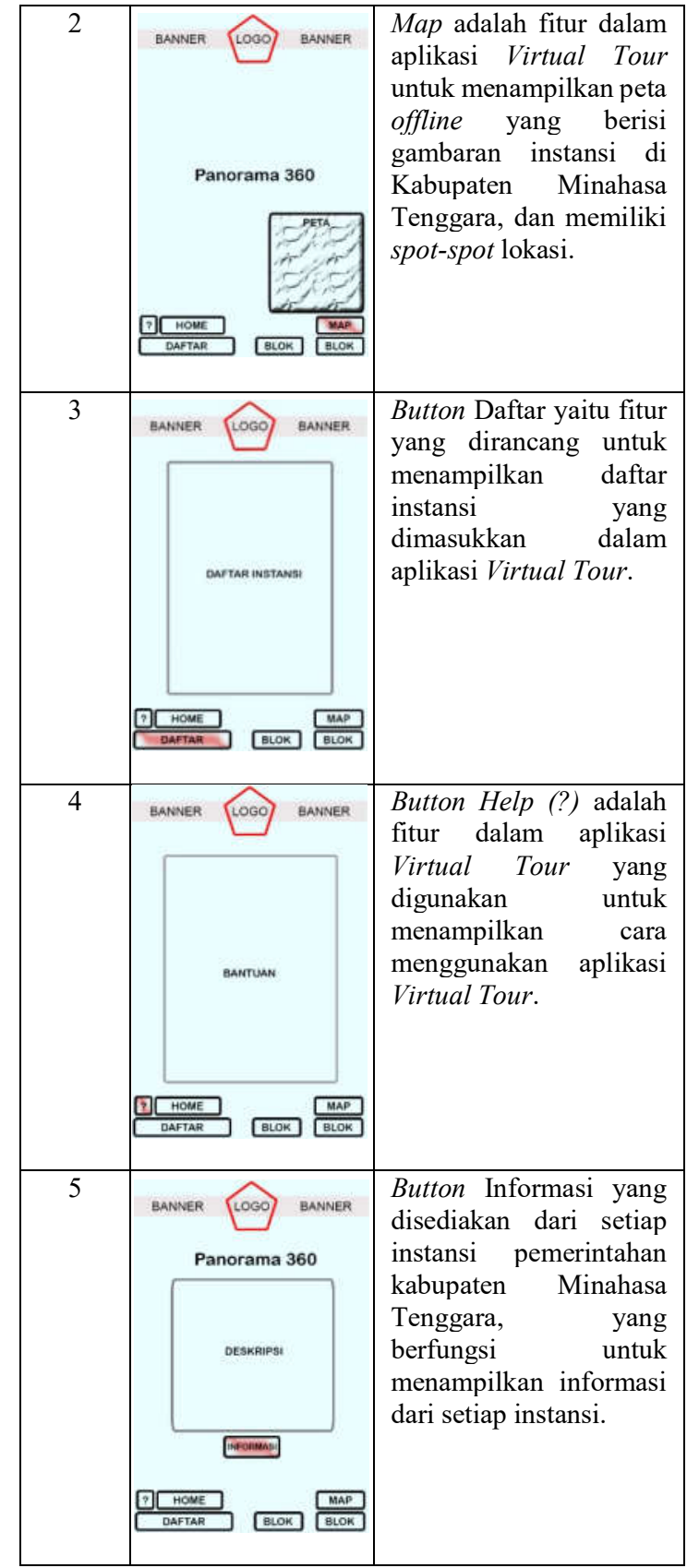


Bryant R. S. Ngongoloy - Virtual Tour Instansi Pemerintahan Kabupaten Minahasa Tenggara

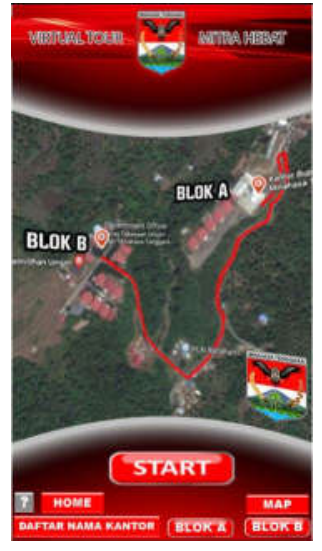

Gambar 4. Halaman Awal

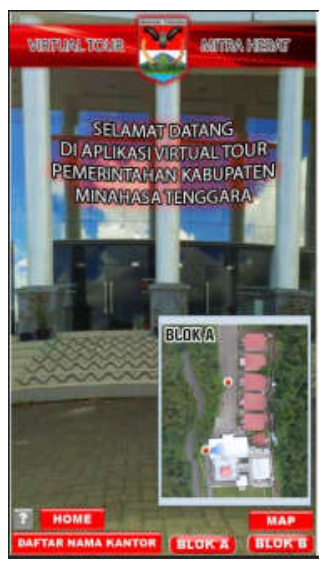

Gambar 5. Halaman Peta

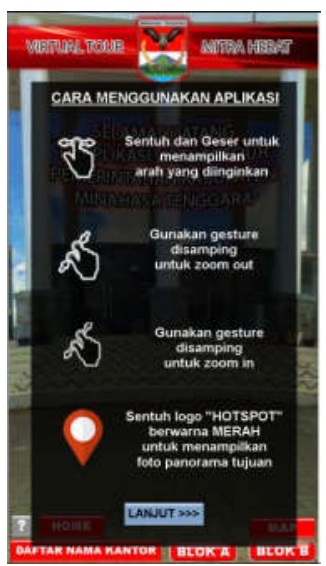

Gambar 6. Halaman Fitur Bantuan

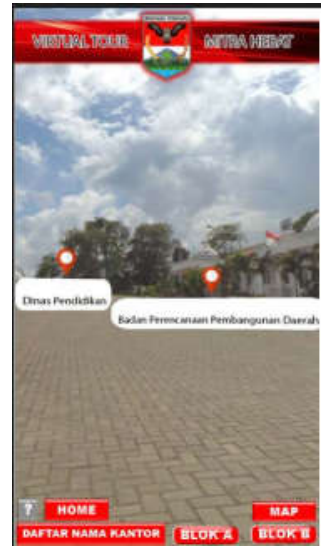

Gambar 7. Halaman Tampilan Hotspot

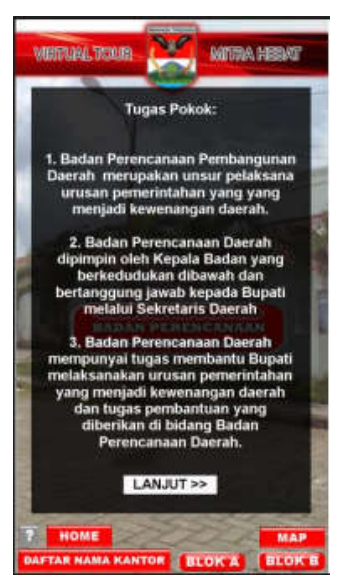

Gambar 8. Halaman Informasi Lokasi

\section{Material Collecting}

1) Kepustakaan

Peneliti melakukan pengumpulan data yang di peroleh secara langsung dari Pemerintahan Kabupaten Minahasa Tenggara, data yang diperoleh dari Sekretariat Daerah yang berisikan lokasi serta informasi dari lokasi yang akan dibuat menjadi virtual tour serta mengumpulkan data yang di peroleh dari buku - buku serta karangan ilmiah yang ada hubungannya dengan masalah yang akan dibahas, baik dari media cetak maupun internet yang berhubungan dengan virtual tour.

\section{2) Kuesioner}

Pada tahap ini yang dilakukan yaitu, membagikan kuesioner kepada seluruh masyarakat menggunakan media google docs dengan pengambilan data secara online. Untuk mengetahui lokasi instansi Pemerintahan Kabupaten Minahasa Tenggara dan untuk mengetahui apakah responden tertarik untuk menggunakan aplikasi Virtual Tour instansi Pemerintahan Kabupaten Minahasa Tenggara. 


\section{3) Observasi}

Dengan teknik ini peneliti melakukan pengamatan langsung terhadap 18 instansi atau terdapat 21 titik spot lokasi yang menjadi objek dalam pembuatan aplikasi virtual tour.

\section{HASIL DAN PEMBAHASAN}

\section{Assembly}

Berdasarkan desain yang telah dibuat di bab III sesuai dengan data lokasi yang diperoleh dari Pemerintahan Kabupaten Minahasa Tenggara sebanyak 21 titik lokasi, berdasarkan data tersebut maka dilakukan proses pengambilan gambar di setiap lokasi. Langkah selanjutnya adalah proses penyambungan untuk menjadi gambar panorama $360^{\circ}$ dengan menggunakan aplikasi panoweaver.

Selanjutnya diperlukan aplikasi tourweaver untuk membuat aplikasi virtual tour yang mana aplikasi akan menampilkan panorama $360^{\circ}$ dari setiap lokasi, menampilkan informasi dari setiap lokasi, menampilkan layanan publik dan menampilkan peta instansi Kantor Bupati Minahasa Tenggara di dalam aplikasi dengan menekan fitur hotspot sebagai link untuk menuju ke lokasi lainnya.

Gambar 4 merupakan halaman awal dari aplikasi virtual tour, pada halaman awal ini menampilkan map yang mengarahkan pengguna untuk lebih memudahkan menemukan lokasi Kantor Bupati Minahasa Tenggara, teks, fitur informasi bantuan, map, gambar 360, hospot, dan logo Pemerintahan Kabupaten Minahasa Tenggara.

Gambar 5 merupakan halaman tampilan dari peta lokasi dari instansi Pemerintahan Kabupaten Minahasa Tenggara, User dapat menekan fitur Maps dengan button map pada halaman awal maka peta instansi akan muncul, tampilan map yang ditampilkan bergantung pada lokasi yang dituju baik dari Blok A dan Blok B, user dapat memilih salah satu lokasi dengan mengklik marker yang ada didalam peta maka gambar lokasi akan di tampilkan dalam pandangan $360^{\circ}$.

Gambar 6 merupakan halaman tampilan fitur bantuan dari aplikasi yang mempermudah pengguna dalam menggunakan aplikasi, dikarenakan dalam fitur bantuan akan dijelaskan bagaimana cara menggunakan aplikasi.

Gambar 7 merupakan tampilan hotspot dari titik lokasi yang disediakan dalam suatu sisi tampilan panorama $360^{\circ}$. Maka pengguna dapat menggunakan titik-titik lokasi hotspot untuk menampilkan tempat atau berpindah tempat lokasi yang diinginkan.

Gambar 8 merupakan halaman informasi dari setiap lokasi, user dapat mengarahkan dan menekan button informasi dari setiap lokasi dan instansi, maka informasi dari lokasi tersebut akan ditampilkan. Hal ini untuk mempermudah user dalam memperoleh informasi mengenai lokasi tersebut.

\section{E. Testing}

Pengujian menggunakan pengujian BlackBox dan peneliti melakukan pengujian sebanyak 15 kali untuk mengetahui fungsi dari setiap atribut yang ada didalam aplikasi berjalan dengan baik sebelum di distribusi, dapat dilihat pada tabel III.

TABEL III

PENGUJIAN BLACKBOX

\begin{tabular}{|c|c|c|c|}
\hline Feature & Expected Result & $\begin{array}{c}\text { Meet } \\
\text { Expectation }\end{array}$ & Comment \\
\hline $\begin{array}{l}\text { Main } \\
\text { Menu }\end{array}$ & $\begin{array}{c}\text { Tampilan awal } \\
\text { dimana User } \\
\text { dapat melihat } \\
\text { button fitur }\end{array}$ & $\mathrm{Ya}$ & $\begin{array}{c}\text { Dapat } \\
\text { dikembang- } \\
\text { kan lebih } \\
\text { menarik } \\
\end{array}$ \\
\hline $\begin{array}{c}\text { Button } \\
\text { Help }\end{array}$ & $\begin{array}{c}\text { User dapat } \\
\text { melihat cara } \\
\text { mengoperasikan } \\
\text { aplikasi Virtual } \\
\text { Tour } \\
\end{array}$ & $\mathrm{Ya}$ & \\
\hline $\begin{array}{l}\text { Button } \\
\text { "Daftar } \\
\text { Nama } \\
\text { Kantor" }\end{array}$ & $\begin{array}{c}\text { User dapat } \\
\text { melihat daftar } \\
\text { nama kantor yang } \\
\text { tersedia dalam } \\
\text { aplikasi Virtual } \\
\text { Tour } \\
\end{array}$ & $\mathrm{Ya}$ & \\
\hline $\begin{array}{c}\text { Button } \\
\text { MAP }\end{array}$ & $\begin{array}{c}\text { User dapat } \\
\text { menggunakan } \\
\text { button radar pada } \\
\text { map untuk } \\
\text { melihat posisi } \\
\text { dan berpindah } \\
\text { lokasi tampilan }\end{array}$ & $\mathrm{Ya}$ & $\begin{array}{c}\text { Dapat } \\
\text { dikembangkan } \\
\text { selanjutnya }\end{array}$ \\
\hline $\begin{array}{c}\text { Button } \\
\text { "BLOK } \\
, "\end{array}$ & $\begin{array}{c}\text { User dapat } \\
\text { berpindah lokasi } \\
\text { 'BLOK' dengan } \\
\text { menyentuh button } \\
\text { 'BLOK' }\end{array}$ & $\mathrm{Ya}$ & \\
\hline $\begin{array}{c}\text { Foto } \\
\text { Panora } \\
\text { ma } 360 \\
\text { dejarat }\end{array}$ & $\begin{array}{c}\text { User dapat } \\
\text { melihat tampilan } \\
\text { foto panorama } \\
\text { secara } 360 \text { derajat }\end{array}$ & $\mathrm{Ya}$ & $\begin{array}{c}\text { Percobaan } \\
\text { untuk tampilan } \\
\text { panorama } 360 \\
\text { derajat berhasil } \\
\text { dengan resolusi } \\
1280 \times 720 \\
\text { pixel. } \\
\end{array}$ \\
\hline $\begin{array}{l}\text { Button } \\
\text { Informa } \\
\text { si }\end{array}$ & $\begin{array}{c}\text { User dapat } \\
\text { melihat informasi } \\
\text { dari setiap lokasi } \\
\text { instansi } \\
\end{array}$ & $\mathrm{Ya}$ & \\
\hline $\begin{array}{l}\text { Button } \\
\text { Pindah } \\
\text { Titik }\end{array}$ & $\begin{array}{c}\text { User dapat } \\
\text { melakukan } \\
\text { perpindahan titik } \\
\text { dalam satu lokasi }\end{array}$ & Ya & \\
\hline
\end{tabular}

\section{F. Distribution}

Pada tahap ini project yang telah selesai kemudian dilakukan pemaketan aplikasi. Dalam aplikasi virtual tour ini, file aplikasi dikemas menjadi sebuah file bertipe apk. Ukuran aplikasi ini adalah 73,8 MB. Aplikasi ini hanya bisa dijalankan dengan sistem operasi Android. Aplikasi ini didistribusikan ke Sekretariat Daerah Pemerintahan Kabupaten Minahasa Tenggara. 


\section{PENUTUP}

\section{A. Kesimpulan}

Berdasarkan hasil dari penelitian yang telah dilakukan dalam pembuatan aplikasi Virtual Tour Instansi Pemerintahan Kabupaten Minahasa Tenggara sebagai media pengenalan kantor dan memberikan informasi terkait dalam pemerintahan dan pelayanan publik dengan menggunakan teknologi Virtual Tour panorama $360^{\circ}$, maka penulis dapat mengambil kesimpulan, sebagai berikut :

- Dari hasil perancangan aplikasi dengan teknologi virtual tour sebagai media interaktif untuk pengenalan instansi pemerintahan kabupaten Minahasa Tenggara berhasil dilakukan.

- Penerapan teknologi virtual tour instansi pemerintahan kabupaten Minahasa Tenggara sebagai media informasi dalam bentuk gambar panorama $360^{\circ}$ memudahkan pengguna untuk menerima dan memahami informasi yang diberikan.

B. Saran

Untuk pengembangan lebih lanjut ada beberapa saran mengenai penelitian ini sebagai berikut:

- Aplikasi ini bisa lebih dikembangkan lagi dengan memperbanyak lokasi.

- Pada tahap pengembangan selanjutnya bisa ditambahkan dengan menggabungkan ke peta online, tambahan spot dan media.

\section{DAFTAR PUSTAKA}

[1] Daud, F.R. Virtual Tour Panorama 360 Derajat Kampus Universitas Sam Ratulangi Manado. E-Journal Teknik Informatika, Volume 8, No.1, 2016.

[2] Highton. Scoot. "Paper of Virtual Reality Photography Creating Panoramic and Object Images". China : Library of Congress, 2010.

[3] Kadir A.,Triwahyuni T. Pengantar Teknologi Informasi edisi Revisi. Penerbit Andi. Yogyakarta, 2013.

[4] Osman A, Wahab N.A, dan Mohammad H.I. "Development and Evaluation of an Interactive 360 Virtual Tour for Tourist Destinations. "Journal of Information Technology Impact, Vol 9, No. 3, pp. 173-182, 2009.

[5] Situs Resmi : Tentang Pentingnya Pelayanan Bidang Kependudukan. [Online]. Tersedia di : http://www.dukcapil. kemendagri.go.id/detail/pentingnya-pelayanan-bidangkependudukan, 2014. [Diakses Tanggal 20 Mei 2017]

[6] Situs Resmi : Tentang EasypanoTourweaver.[Online]. Tersedia di : http://www.easypano.com/ [Diakses Tanggal 20 Mei 2017]

[7] Sutopo, A. H. Teknologi Informasi dan Komunikasi dalam Pendidikan. Yogyakarta: Graha Ilmu, 2012.

[8] Umafagur F. Implementasi Virtual Tour Sebagai Media Informasi Daerah (Studi Kasus : Kota Manado). E-journal Teknik Informatika, Volume 9, No. 1, 2016.

[9] Vaughan, T. Multimedia: Making It Work. Edisi Enam. Yogyakarta : Andi, 2004.

[10] Wullur, H. Aplikasi Virtual Tour Tempat Wisata Alam Di Sulawesi Utara. E-Journal Teknik Informatika, Volume 6, No. 1, 2015.

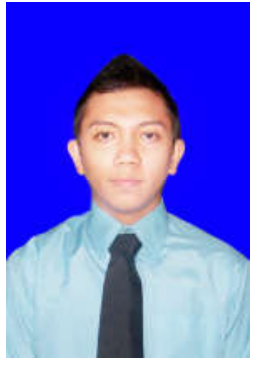

Penulis bernama lengkap Bryant Rino Samuel Ngongoloy, anak pertama dari dua bersaudara. Lahir di Manado, Sulawesi Utara, pada tanggal 28 November 1994. Dengan alama tempat tinggal sekarang di Kelurahan Malalayang Dua kota Manado. Pendidikan formal yang pertama ditempuh adalah Taman Kanak - Kanak BNI Manado. Selanjutnya, melanjutkan ke Sekolah Dasar Kristen Tabita Manado. Kemudian menempuh bangku Sekolah Menengah Pertama di SMP Kr. Eben Haezar Manado. Dan selanjutnya menyelesaikan pendidikan formal Sekolah Menengah Atas di SMA Kr. Eben Haezar Manado. Setelah lulus tahun 2012 melanjutkan ke Perguruan Tinggi di Universitas Sam Ratulangi Manado dengan mengambil Jurusan Teknik Informatika. Pada tahun 2017, penulis membuat Skripsi demi memenuhi syarat Sarjana (S1) dengan penelitian berjudul Virtual Tour Instansi Pemerintahan Kabupaten Minahasa Tenggara, yang dibimbing oleh dua dosen pembimbing yaitu Yaulie D.Y. Rindengan, ST.,MSc.,MM dan Sherwin R.U.A Sompie, ST.,MT, sehingga pada tanggal 13 Juli 2018 penulis resmi lulus di Teknik Informatika Universitas Sam Ratulangi Manado dan menyandang gelar Sarjana Komputer dengan predikat sangat memuaskan. 